\title{
EFL teachers' motivation and competence in an Indonesian context as assessed within the framework of Maslow's and Herberg's theories
}

\author{
Anna Riana Suryanti Tambunan ${ }^{1}$, Fuad Abdul Hamied ${ }^{2}$, and Wachyu Sundayana ${ }^{3}$ \\ English Education and Literature, Faculty of Language and Art, Universitas Negeri Medan, Medan, North Sumatera, \\ Indonesia ${ }^{1}$ \\ English Language Education Department, Faculty of Language and Literature, Universitas Pendidikan Indonesia, \\ Bandung, West Java, Indonesia ${ }^{2,3}$
}

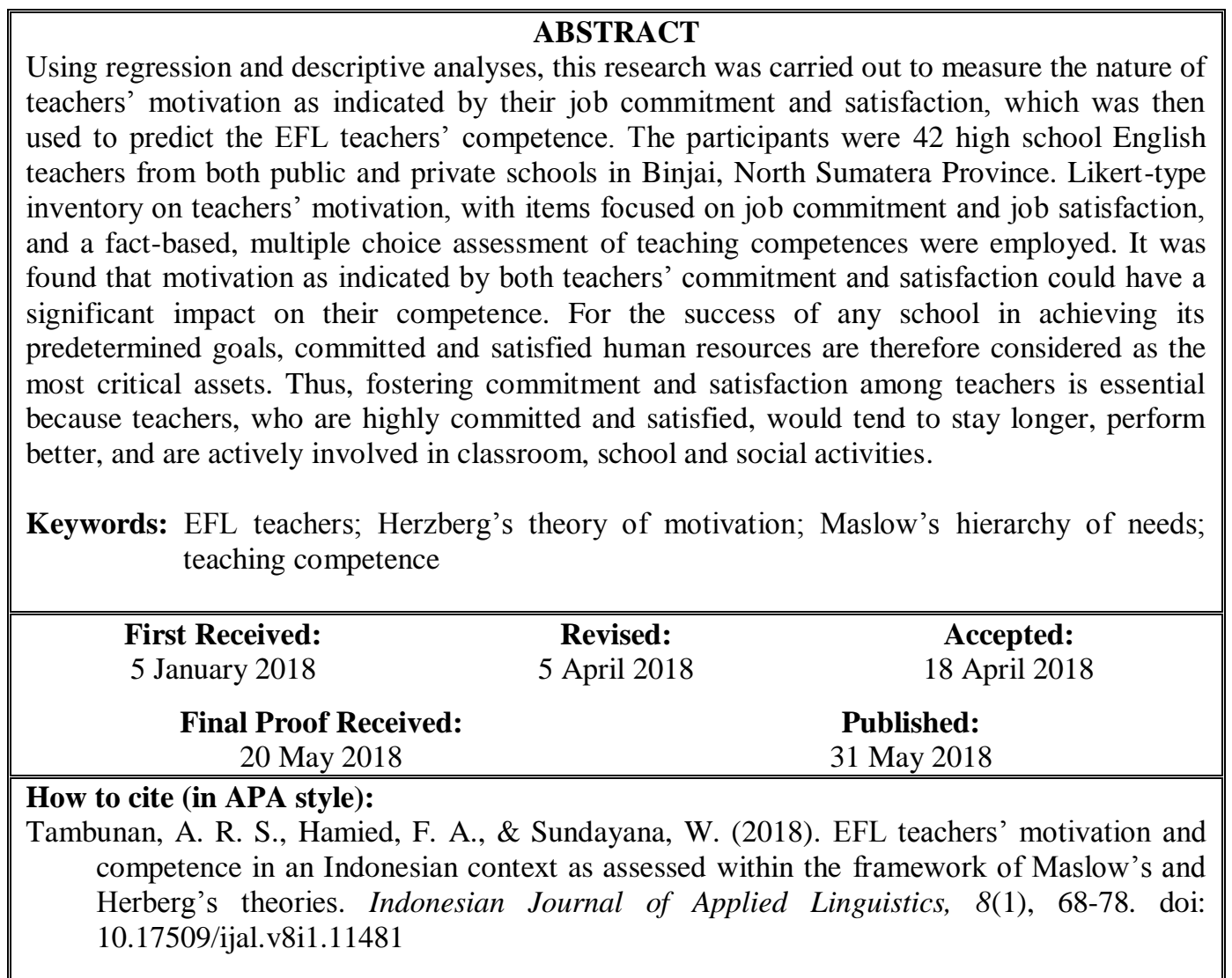

\section{INTRODUCTION}

A teacher's motivation in general plays a vital role in promoting the teaching-learning excellence. Motivation is an essential factor which could directly affect student motivation and achievement levels in the target language. Bernaus, Wilson, and Gardner (2009) in their study point out that "The motivation of teachers is the most important variable because if teachers are not motivated the whole idea of the use of the strategy is missing" (p. 29). The extent to which teachers can motivate their students depends on how driven the teachers are themselves (Guilloteaux \& Dörnyei, 2008;
Bernaus, Wilson \& Gardner, 2009). This statement is supported by Celep (2000), reporting that students can be motivated if they have efficient and motivated teachers. Dornyei and Ushioda (2011) imply that the student learning with the motivated teachers is most likely driven to learn.

Though there has been a lot of research on teachers' motivation in general and its relatedness to teachers' competence, the manifestation of teachers' motivation in urban EFL teachers' contexts is a specific and under-researched area. Urban educators often face unique and substantial challenges that could serve as 
obstacles to sustaining their motivation to work as teachers. So, examining motivation concerning the teachers' job commitment and satisfaction for urban teachers, specifically, could help shed light on how these sub-constructs may be related to teachers' competence in this special population. Thus, the objective of this study is to investigate the nature of teachers' motivation, concerning the teachers' job commitment and satisfaction, and how it may predict the competence for urban EFL teachers in Indonesia.

Among various behavioral theories long generally believed and utilized by different institutions especially in the US are those of Herzberg and Maslow. Herzberg put forward a theory about job factors that could motivate employees. On the other hand, Maslow developed a theory about human needs and how people fullfil these needs (Gawel, 1997). They both touched upon motivation as an important factor in human dayto-day struggles. Motivation derives from the Latin word 'movere,' that means 'to move' (Pintrich, 2003). There are some definitions of motivation. From a psychological perspective, Reber and Reber (2001) considered motivation as an "energizer of behavior" ( $p$. 447) and alternatively it can be considered as the propensity of an individual to expend effort at work (Heery \& Noon, 2001, p.226). Furthermore, Ofoegbu (2004), in research on teachers' motivation, found that motivation stimulates appropriate behavior and it is required to ensure that teachers perform their duties (Davidson, 2007). All these definitions lead to the conclusion that without motivation, there is no behavior. There are many theories on motivation; however, there are two that best support the goals and aims of this study due to their relatedness to teachers' job satisfaction and job commitment: Maslow's hierarchy of needs theory, and Herzberg's two-factor theory of motivation.

Maslow's (1987) needs-based theory of motivation is arguably one of the most widely recognized theories of motivation and perhaps the most referenced of the content theories which focus on the factors that start, energize, direct, maintain and stop the behavior. According to this theory, a person has five fundamental needs: physiological, safety/security, social/affiliation, esteem, and self-actualization. Physiological needs consist of the need for primary biological needs which includes the need for food, water, air, sexual gratification and other fundamental needs such as shelter, clothing, excellent and comfortable work conditions, etc. In the school system, the salary one earns enables him/her to satisfy this needs but if unfulfilled then it could result in dissatisfaction which affects productivity and quality performance in the workplace.

Security/safety needs emerge once the physiological requirements have been achieved. This includes the need for security, safety, protection against danger and accidents (threats, deprivation, psychological harm, economic disaster) and stability in the physical and internal events of the day to day life. In the school, teachers want to have the feeling that their job is secured and accommodation also acquired. Social/affiliation needs include the need for love, affection, companionship, acceptance, and friendship, sense of belongingness in one's relationship with others. In the school, social needs of teachers are usually satisfied if informal groups and teachers' participation in decision making are encouraged, membership in groups also helped and proper delegation of duty.

The higher needs include the ego or esteem needs involving the need for respect, prestige, recognition, self- esteem, status, personal sense of competence. For teachers, esteem needs to be satisfied in the school will involve delegating duties to the lower rank with the freedom to exercise power to an extent by high officers; recognition of teachers capabilities and competence; job title and responsibilities; performance recognition through financial benefits or merit pay, praise and commendations. The self-actualization needs involve the need for growth, achievement, advancement and to fulfill one's self (Peretomode, 1991). However, to accomplish teachers' self-actualization needs will entail allowing them to become more and more what one is capable of becoming or creative becoming.

Herzberg's two-factor theory, as outlined in Herzberg, Mausner and Snyderman (1959), is heavily based on need fulfillment because of their interest in how best to satisfy workers. The hygiene factors are company policy and administration, technical supervision, salary, interpersonal relationship with supervisors and work conditions; they are associated with job content. Herzberg et al. indicated that these factors are perceived as necessary but not sufficient conditions for the satisfaction of workers. They further identified motivating factors as those factors that make workers work harder. They posited that these factors are associated with job context or what people do in their work and classified them as follows: achievement, recognition, work itself, responsibility and advancement. Success is represented by the drive to excel, accomplish challenging tasks and achieve a standard of excellence. Individuals' need for advancement, growth, increased responsibility and work itself are said to be the motivating factors. At school, factors which can lead to job satisfaction are known as motivators, e.g. recognition in the workplace, job enrichment, advancement, and achievement. Meanwhile, such factor which can lead to job dissatisfaction is known as hygiene factors, e.g. company policy and administration, strict supervision, interpersonal relation and lousy working conditions.

Teachers' motivation has to do with teachers' attitude to work. It has to do with teachers' desire to participate in the pedagogical process within the school environment. It has to do with teachers' interest in student discipline and control particularly in the classroom. Teachers who are motivated are more productive and can influence students' achievement, productivity, and attrition. Teachers who are not motivated impact negatively on student learning (Otube, 
2004). A teacher who has a high work motivation will produce the peak competence and performance and vice versa (Siagian, 2004). Therefore it could underlie the teachers' involvement or non-involvement in academic and non-academic activities, which operate in schools, as necessary.

Teacher motivation should be a significant concern in developing education in a country. Challenges like unbalanced distribution of teachers, especially in the developing country, like Indonesia, and the low levels of motivation among teachers need to be addressed by maintaining motivation among them. Although the enthusiasm and good intentions may not be sufficient to improve the quality of education, motivation is necessary to survive in facing a difficult situation. Also, the fact that teachers in developing countries are not always trained and, even if they are trained, they may not be competent, effective and efficient (Lockheed \& Verspoor, 1991). Without teachers who are motivated, children are likely not to achieve the desired level of education. Teachers who are qualified, trained and motivated have a positive effect on motivation and performance of students (Towse, Kent, Osaki, \& Kirua, 2002).

The set of knowledge, skills, and experience necessary for the future, which manifests in activities, are defined as the competence that the teachers are required to have (Katane \& Selvi, 2006). This definition is also understood by Suriyani, Hendriani and Amsal (2014) that the competence is the ability, skill, and knowledge of a person in a particular field. So the word competence is defined as the sufficient skill to perform a task or a skill and a required skill. It is a characteristic of a person's capabilities to be acquired through learning and education (Singh \& Singh, 2015). In school, as an educational service to the society, this ability displayed by a teacher is required in performing his/her duty. In Indonesia, the term 'competence' is based on the Indonesian Government Regulation number 14 Year 2005. It is stated in the law, "Competence is the set of knowledge, skill, and attitude, which teacher and lecturer should have, to do their professional duties" (Law number 14 Year 2005). Later, through the Regulation of Minister of National Education number 16 Year 2007, the government sets four competencies that a teacher should own. They are pedagogy, professional, social, and personal competencies.

\section{Purpose of the Study}

In addition to filling a notable gap in the urban teacher motivation literature, the impetus for this study comes from several areas. First, there were several research reports found on teachers in developing countries, undertaken by Voluntary Service Overseas (VSO) in the U.K in 2002. A primary finding was that teachers' motivation was fragile and declining. The second report also noted that "there is a strong link between teachers' motivation and performance, and education quality, but improving teachers' motivation is not uniformly prioritized as a major concern of national and international policy-makers" (VSO, 2002, p.2). The report also adds that addressing factors that could reduce teachers' motivation should be a major concern of policymakers to create conditions for the success of education interventions. Based on these reports, it is concluded that teachers' motivation is a significant issue and concern to explore in our schooling context, especially in urban schools. Second, the issue of teachers' motivation as indicated by the teachers' job commitment and satisfaction, and its relationship to teachers' competence has received relatively less attention in educational psychology literature, especially when it concerns urban EFL teachers in Indonesia. There seem to have been very few studies discussing the nature of the 'motivation to teach' in this particular population; although some work has been done on related issues such as teachers' job satisfaction, stress, and burnout (Dinham \& Scott, 2000; Zhang \& Sapp, 2008). The limited research conducted on the teacher motivation calls for more exploration of this topic; especially for teachers in schools in a newly organized urban center. Thus, this study was conducted to explore urban EFL teachers' motivation and its relationship to their teaching competence in a somewhat rarely researched population.

The objective of this study is to examine the nature of teachers' motivation as demonstrated by job commitment and satisfaction, and how it may predict the competence of urban EFL teachers. To meet this objective, the study addressed the following research question: Does urban EFL teachers' motivation as indicated by their job commitment and satisfaction significantly predict the level of the teachers' competence? It was then hypothesized that the level of teachers' competence could be reliably predicted by levels of teachers' motivation. Understanding the predictive relationship between teachers' competence and teacher motivation as indicated by their job commitment and satisfaction could facilitate the development of educational policy and practice especially as regards improvement of teachers' job commitment and satisfaction, which could then eventually help in retaining good teachers-especially in urban areas.

\section{METHOD \\ Research Design}

To respond to the research question, a quantitative approach was adopted, specifically, utilizing simple linear regression for data analyses. Teacher motivation was assessed using the scores from the Teachers' Motivation Questionnaire (TMQ), while the teachers' competence was indicated by the scores on the Test of Competence (ToC). These two variables made up the regression model.

\section{Sites and Sampling}

This study took place in a newly established city in a northern part of the island of Sumatera in Indonesia. 
The target population was English teachers. The sample of teachers was drawn from twenty-six senior high schools, consisting of nineteen private schools and seven public schools. The senior high school level was chosen due to the importance of this layer of education in preparation of the students' success in their upcoming higher education. Teachers were selected by using convenience sampling which encompassed two categories of teachers: (1) those who were civil servants or full-timers and (2) those who taught in one district.

The diverse sample consisted of 42 urban school English teachers, 14 males, and 28 females, who ranged in age from 20 - 69 and was from various ethnic groups. They had varying years of teaching experience, ranging from $<1$ year to $>6$ years. Some were from public schools $(\mathrm{n}=7)$ and some other from private schools (n $=19$ ).

\section{Data Collection}

The primary techniques for data collection were the use of closed-ended, paper-and-pencil instruments. This method was adopted because it assured anonymity and permitted more comprehensive coverage of respondents who were geographically dispersed and items were consistently delivered and could be easily scored. Two instruments were used: the Teachers' Motivation Questionnaire (TMQ) and the Test of Competence (ToC).

The Teachers' Motivation Questionnaire (TMQ) consists of forty-three statement items in English, and was used to assess teachers' motivation. The participants rated their agreement to each statement using a 5-point Likert scale rating (i.e., 1-strongly disagree, 2-disagree, 3-undecided, 4-agree, 5-strongly agree). There were 24 job commitment statements, based on Maslow's theory, which addressed the physiological needs, social needs, security needs, selfactualization needs and ego/esteem needs. Then, there were 19 job satisfaction statements, based on Herzberg's Theory, which covered the work itself, recognition, achievement/advancement, administrative support, company policy and administration, working/teaching environment, working conditions, relationship with supervisors, and job enrichment.

To derive a score from this instrument, the Likert scale responses were converted into numerical values by summing each participant's ratings and totaling each participant's score. These scores were used to determine reliability evidence using Cronbach's alpha. Ideally, the reliability index would be .70 or higher. The reliability index of the 43 items was .898. Having calculated the reliability, a validity test using item correlation analysis was conducted to determine evidence for the validity of scores for this sample. Item correlations ranged from .032 to .691 and the minimum significant association was .304; thus any item with a relationship less than this benchmark was deemed invalid and deleted.

The Test of Competence (ToC) consists of thirty (30) fact-based, multiple-choice items designed to assess several areas of teaching competence. The items were developed based on the Indonesian Teacher Law (Law No. 14, 2005) covering pedagogic competence and professional competence. The teachers' pedagogic competence consists of the ability to (a) recognize students' characteristics and their potential, (b) master the learning theories and the principles of effective learning, (c) master the curriculum plan and development, and (d) master the system, mechanism and procedure of assessment. The teachers' professional competence consists of the ability to (a) master the content, structure, concept, and scientific thinking pattern to support the lesson taught, (b) master the scientific methodology which fits the task given, and (c) master the real essence of the profession as a teacher. The scoring process consisted of summing the number of correct answers (counted 30 as the highest score) and totaling each participant's score.

\section{FINDINGS}

Descriptive analyses were used to provide summaries for demographic data of participants and to summarize data from the TMQ and ToC instruments and screen it in preparation for the regression analysis, and the correlation was used to determine if there was a relationship between teachers' motivation and teachers' competence. Regression analysis was used to answer the research question and assess evidence to test the hypothesis. The scores from TMQ were used to determine reliability evidence using Cronbach's alpha. Ideally, all variables would have a reliability score of 0.70 or higher. The statistical reliability of the 43 items was 0.898 . It can be concluded that all statements in TMQ were of very high consistency. The scores from ToC were used to determine reliability evidence using KR 20. Ideally, all variables would have a reliability score of 0.70 or higher. The reliability statistics of the 30 questions was 0.879 . It can be concluded that the value of the test of competence scores was also of very high consistency.

\section{Teachers' job commitment}

In his theory, Maslow claims that human beings have desires, wants and needs. Those human needs are arranged in a hierarchy beginning with the most basic to the highest. These are (1) physiological needs, (2) safety or security needs, (3) social and belonging or affiliation needs, (4) Self-esteem, ego or status needs and (5) the need for self-actualization. The figure below reflects the teachers' job commitment.

Figure 1 presents a summary of the sub-scores computed from items that comprise TMQ as indicators of job commitment. As shown, self-actualization needs are the highest $(81.27 \%$ ) as a factor indicating teachers' job commitment, followed by social needs $(80.12 \%)$, ego/esteem needs (77.01), physiological requirements $(73.21 \%)$, and security needs $(70.95 \%)$. Selfactualization has been considered as the number one factor in the teachers' commitment to their job, whereas security has been placed at the lowest position. 
Teachers' job satisfaction

Within Herzberg's theory, the teachers identify five factors that could influence both motivation and job satisfaction and these include: recognition, achievement, advancement, responsibility, and work itself. This implies that they also found that a different set of factors could be the determinants of job dissatisfaction. These include company policy and administration, supervision, salary, interpersonal relation and working condition, as reflected in the following figure.

Figure 2 displays a summary of the sub-scores computed from items that comprise the TMQ concerning the teachers' job satisfaction. As shown, the top five are recognition, the highest score $(86.19 \%)$ as an indicator of job satisfaction, followed by job enrichment and work (84.76\%), advancement (84.13\%), and environment place to work/teach $(82.86 \%)$.

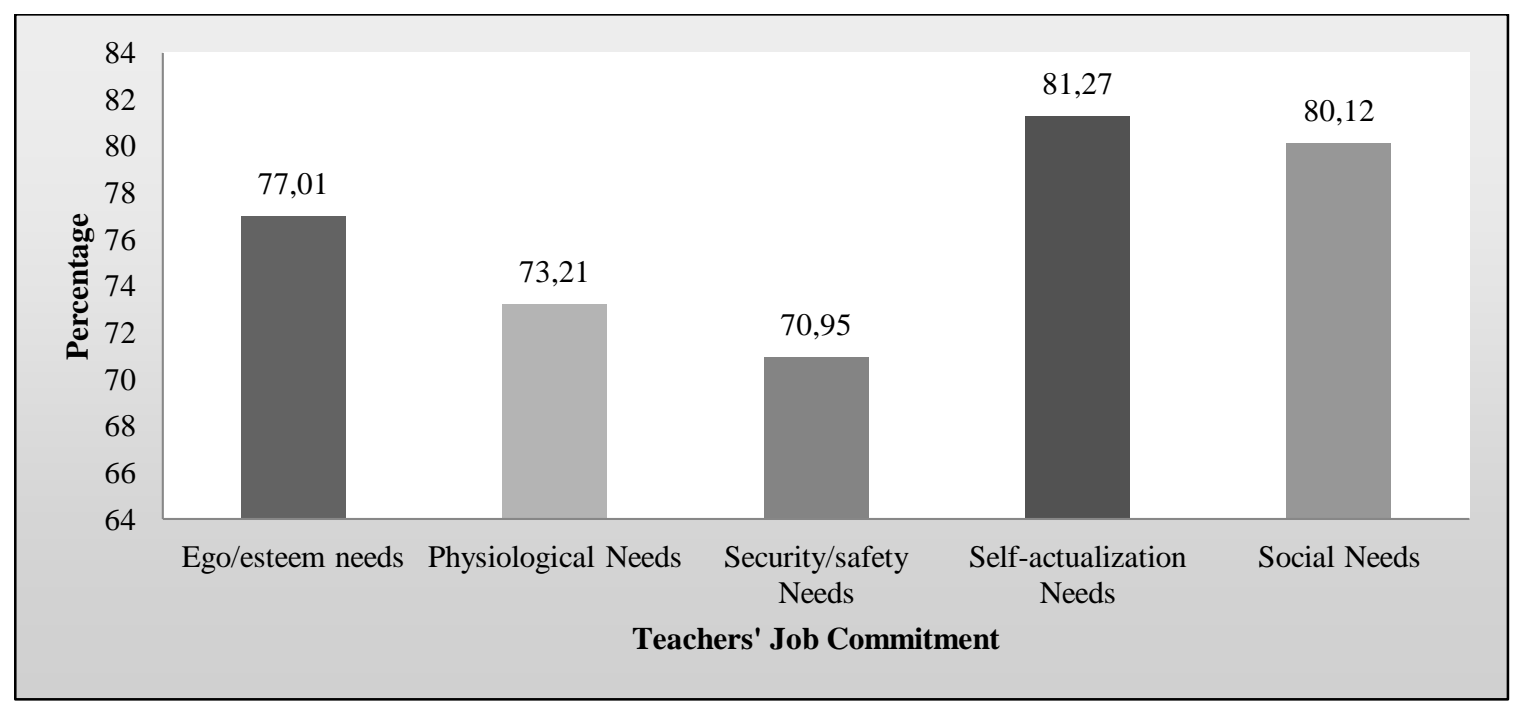

Figure 1. Teachers' job commitment

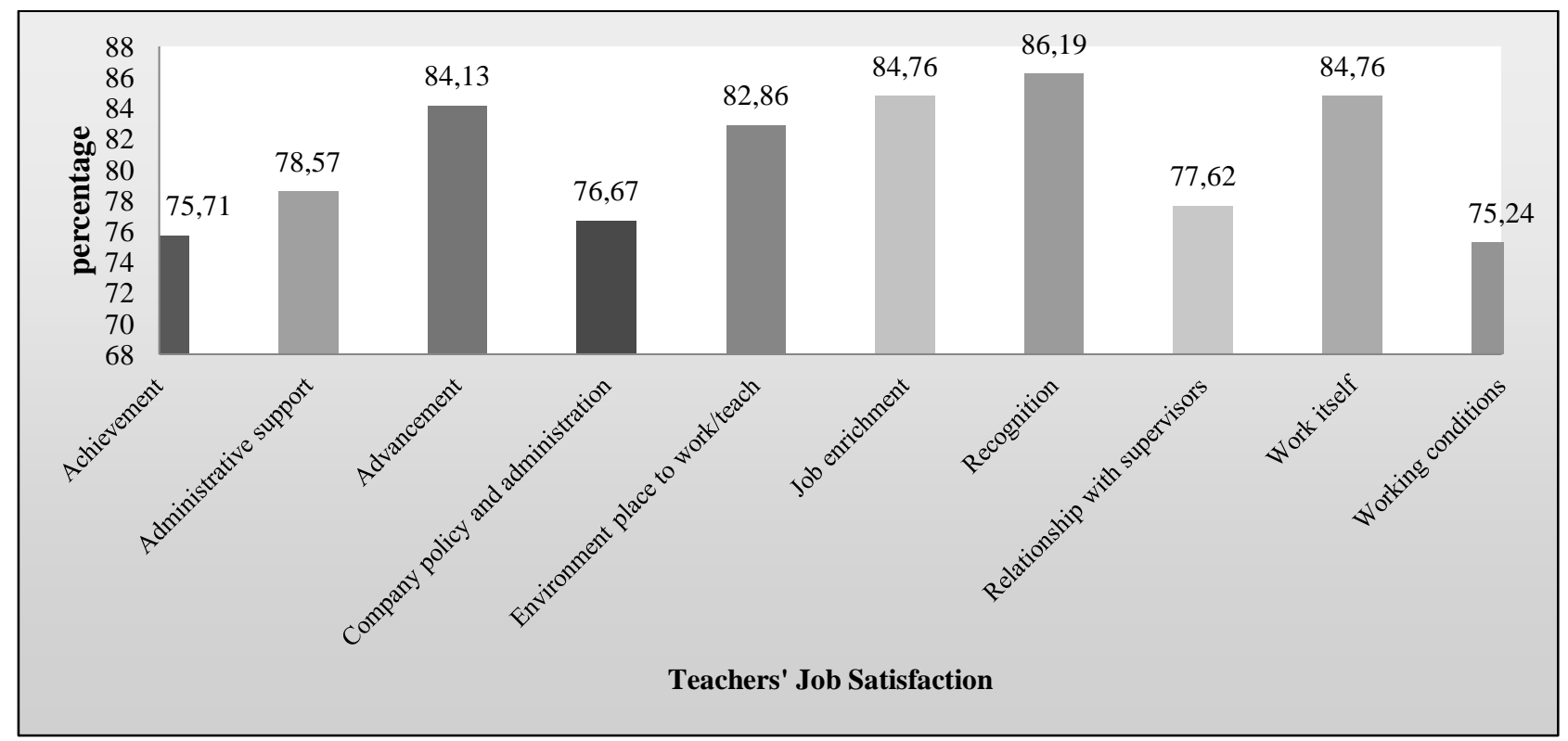

Figure 2. Teachers' job satisfaction

\section{Statistical Analyses}

When regression analysis is carried out, as can be seen in Table 1 above, the value of the determinant coefficient from the R- Square is 0.236 . It shows that $23.6 \%$ of teachers' competence (Y) can be explained by teachers' job commitment (X1) and teachers' job satisfaction (X2), while the remaining $76.4 \%$ could be explained by other factors that are not examined in this study. When simultaneous test in this study was calculated, the results of the analysis can be seen in Table 2. 
Table 1. Multiple regression analysis Model summary ${ }^{b}$

\begin{tabular}{rlccc}
\hline Model & R & R Square & $\begin{array}{c}\text { Adjusted R } \\
\text { Square }\end{array}$ & $\begin{array}{c}\text { Std. Error of the } \\
\text { Estimate }\end{array}$ \\
\hline 1 & $.486^{\text {a }}$ & .236 & .197 & 3.074 \\
\hline a. & Predictors: (Constant), X2, X1 \\
b. & Dependent Variable: Y & \\
\hline
\end{tabular}

Table 2. Simultaneous test (F-test)

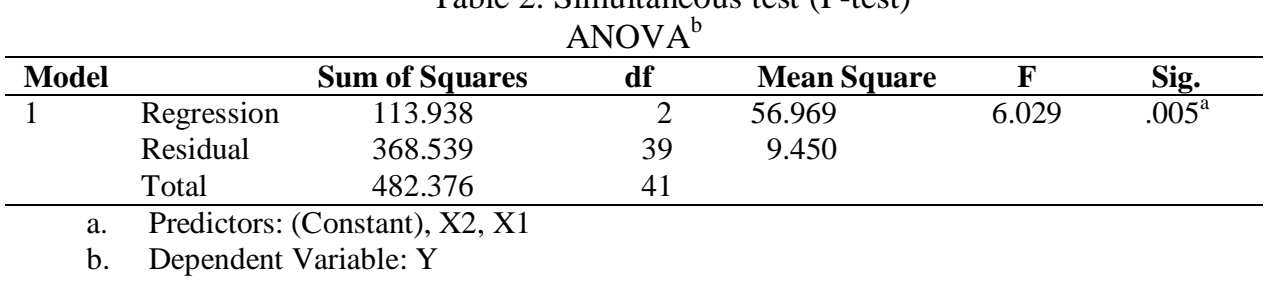

Based on Table 2, it shows that the value of $\mathrm{F}$ (6.029) is greater than the value of F table (3.12), and sig. $\alpha(0.000)$ is smaller than $\alpha 5 \%(0.05)$. It can be concluded that teachers' job commitment and teachers' job satisfaction, as the dimensions of teachers' motivation, have a simultaneously positive and significant impact on the competence of the teachers. It suggests that teachers' motivation significantly contribute to the teachers' competence. From another statistical analysis, a different perspective could also be put forward. Partial test results of the analysis can be seen in Table 3.

Table 3. Partial test results

\begin{tabular}{|c|c|c|c|c|c|c|c|c|}
\hline \multirow[b]{3}{*}{ Model } & & \multicolumn{5}{|c|}{ ANOVA $^{\mathrm{b}}$} & \multirow{2}{*}{\multicolumn{2}{|c|}{ Colinearity Statistics }} \\
\hline & & \multicolumn{2}{|c|}{$\begin{array}{c}\text { Unstandardized } \\
\text { Coefficients }\end{array}$} & \multirow{2}{*}{$\begin{array}{c}\begin{array}{c}\text { Standardized } \\
\text { Coefficients }\end{array} \\
\text { Beta }\end{array}$} & \multirow[b]{2}{*}{$\mathbf{t}$} & \multirow[b]{2}{*}{ Sig. } & & \\
\hline & & B & Std. Error & & & & Tolerance & VIF \\
\hline 1 & Constant & -.784 & 6.144 & & -.128 & .899 & & \\
\hline & $\mathrm{X} 1$ & .067 & .062 & .170 & 1.065 & .293 & .769 & 1.301 \\
\hline & $\mathrm{X} 2$ & .190 & .080 & .381 & 2.385 & .022 & .769 & 1.301 \\
\hline
\end{tabular}

a. Dependent Variable: $\mathrm{Y}$

Based on Table 3, it shows that regression equation is as follows: $\mathrm{Y}=-.784+.067 \mathrm{X} 1+.190 \mathrm{X} 2$. It can be seen here that the standardized coefficient of X1 (commitment) to $\mathrm{Y}$ (competence) is .170 with a $\mathrm{p}$-value of .293, bigger than .05, indicating that the pathcoefficient of $\mathrm{X} 1$ to $\mathrm{Y}$ is not significant. This is different from the standardized coeficient of X2 (satisfaction) to $\mathrm{Y}$ (competence), which is ,381 with a p-value of .022, smaller than .05 , indicating that the path-coefficient of
$\mathrm{X} 2$ to $\mathrm{Y}$ is statistically significant.

To see the relationship between teachers' job commitment and teachers' competence, Spearman Bivariate Correlation was utilized. Correlation analysis is used to measure the level of relationship between the variables, not the influence of one on the other (Hamied, 2017). The level of relationship between teachers' job commitment and teachers' competence can be seen in Table 4.

Table 4. Correlation of teachers' job commitment and competence

\begin{tabular}{rlrrr}
\hline \multirow{2}{*}{ Spearman's rho } & & Commitment & Competence \\
& & Commitment & 1.000 & $.393^{* *}$ \\
& & Sig. (2-tailed) &. & .010 \\
& $\mathrm{~N}$ & 42 & 42 \\
\cline { 2 - 5 } & Competence & Correlation Coefficient & $.393^{* *}$ & 1.000 \\
& & Sig. (2-tailed) & .010 &. \\
& $\mathrm{~N}$ & 42 & 42 \\
\hline
\end{tabular}

Based on Table 4, the relationship between job commitment and competence has a low correlation, but is still significant as the coefficient is below .05. Then, the level of relationship between teachers' job satisfaction and teachers' competence is shown in Table 5.

Spearman Correlation shows that there is a medium correlation between the two variables. The table shows that a significant level is at 0.005 point, which is belom .05 , meaning the two variables have a close and significant relationship. This is in line with the results of the regression test which shows that job satisfaction has a significant contribution to the teachers' competence. 
Table 5. Correlation between teachers' job satisfaction and teachers' competence

\begin{tabular}{rllrr}
\hline & & Satisfaction & Competence \\
\hline Spearman's rho & Satisfaction & Correlation Coefficient & 1.000 & $.422^{* *}$ \\
& & Sig. (2-tailed) &. & .005 \\
& N & 42 & 42 \\
\cline { 2 - 5 } & Competence & Correlation Coefficient & $.422^{* *}$ & 1.000 \\
& & Sig. (2-tailed) & .005 & .42 \\
& $\mathrm{~N}$ & 42 \\
\hline
\end{tabular}

**. Correlation is significant at the 0.01 level (2-tailed).

\section{DISCUSSION}

Based on the analysis as reported above, it was found that the teachers' motivation could contribute to their competence by $23.6 \%$. This relatively small portion of contribution may be due to the fact that partially only teachers' job satisfaction had a significant correlation with teachers' competence. Teachers' job commitment does not significantly affect the teachers' competence, although both have a positive relationship to the teachers' competence. The variation of teachers' motivation can explain $23.6 \%$ of the variation of teachers' competence. While the remaining $76.4 \%$ could probably be explained by other variables outside this study. The score obtained is small, but its contribution impacts much on the success of the teaching and learning activities. The logic is that more motivated teachers should be able to influence the teachers' competence and help students learn more effectively, as evidenced by the student gain scores from the test given. Moreover, Siagian (2004) has substantiated that a teacher who has a high work motivation will produce the peak competence and performance and vice versa. It can be said that teachers' motivation impacts not only on the teachers' competence but also directly influences the students' achievement. As Atiya and Jehangir (2012) have declared that "If in schools, the teachers do not have sufficient motivation, then they are less competent which directly influence the students and the education system." This statement shows how teachers' motivation greatly influences students' achievement and education system as well.

This finding concurs with the outcome of Aziz, Akhtar, and Rauf's (2014) study. In their research, it was found that there was a significant positive correlation between motivation and competencies of teachers in each category at higher education level. It shows that the more competent the teachers are, the more the teachers are motivated too. Teachers can play their role as a change agent only when they are qualified and motivated. It is also supported by the work of Abdulsalam and Mawoli (2012). Their study has indicated that there is a moderate positive correlation between motivation and teaching competence, which impacts on the teachers' performance.

Teachers who have high motivation to do the job indicate that the teacher has a high performance. It is consistent with the study done by Sriekaningsih \& Setyadi (2015) who said that motivation has a significant influence on the performance of the lecturers at the State University of East Kalimantan. Likewise, teachers who have low motivation suggest that the teacher has low performance. The results of this study support the previous research conducted by Darni (2012) as well. Her study concluded that there is a relationship between teachers' motivation and teachers' competence. Gayatri (2006) also concludes that there are a positive influence and significant correlation between work motivation, teacher competence and satisfaction of teachers on teacher performance. Similar findings were also reported by Sriyono (2005) who concluded that there is a significant influence of teachers' motivation, work experience and professionalism on teacher performance. It is also in line with the explanations of Gibson (n.d. in Uno, 2008) that a teacher's motivation could be different from other teachers' motivation and this motivational difference could lead to differences in the result of teachers' performance. In a study conducted by Yustiawan and Nurhikmahyanti (2014), it was found that teachers who have been certified have high motivation and influence on their competence in the classroom. It shows that the certification incentives given to the teachers contribute as well to the teachers' motivation which could then impact on the teachers' competence.

Teachers who work with high motivation would tend to also improve their teaching competence, so that their pedagogical competence would be instrumental in uplifting their productivity. In carrying out the task of teaching, teachers should strive to implement its pedagogical competence that is supported by high teaching motivation to improve their teaching effectiveness. This is in line with Mangkunagara and Prabu (2000) who put forward that the factors that affect performance are the capability and the motivational factor. Peck, Fox, and Morston (1977) show that improvement in teacher's motivation has benefits for students and teachers, as it is also emphasized by Bishay (1996) in his study indicating that when teachers are motivated, it benefits the students as well as the teachers themselves. Also, Guilloteaux and Dornyei (2008) found a strong positive correlation between teachers' motivational teaching practices and their learners' learning motivation in the actual classroom. On the other hand, teachers who report low levels of motivation tend to perceive their students' motivation levels as low since teachers' motivation is assumed to affect the teachers' competence and is directly linked to the desire of the teachers to take part in the teaching and learning process (Iliya \& Ifeoma, 2015).

According to Jackson (1997), lack of motivation among teachers has been manifested in the teachers' unwillingness to participate in school activities, poor 
attendance, unexpected absence, late coming, lack of additional training, uncreative and non-stimulating teaching, lack of interest in meetings, unhelpful attitudes when assistance is needed, occurrence of holdups because deadlines aren't kept, resistance to contributing more than what is required of them and development of arguments between colleagues. Astuti (2016) indicated that the critical factor to motivate students' learning in the classroom is the teacher. The students reported that the teacher was the main factor that made the classroom learning process interesting. It also indicated that the teachers play significant roles in motivating their students in learning the language. It is suggested that teachers of English in an Indonesian high school context influence their students' motivation for the success of their students' learning by building a good rapport with them and by deciding appropriate teaching materials and strategies applied in the classrooms. It can be concluded that the role of the teacher is not only teaching but also motivating the students. It implies that the teachers should have their motivation so that they can motivate the students and directly improve the students' achievement.

From the finding as shown in Table 3, it can be seen that there is no significant influence of teachers' job commitment towards teachers' competence. The regression coefficient is .067 , which is positive, but statistically not significant. This means that the commitment, as an aspect of motivation, could affect competence although not in a significant way. This finding is in line with the study done by Sarmawa, Riana, and Suryani (2015) who reported that teachers' job commitment does not significantly affect the teachers' competence. Meanwhile, the finding of this study is a little bit in contrast to the results of a survey, reported by Hamalik (2002) who found that committed teachers significantly affect their quality and responsibility as teachers.

Interestingly, the physiological need, found in this study, is not the most basic need unlike what has been proposed by Maslow's need theory. Based on Maslow's theory, it should be physiological needs that should be met first, at school, With regards to teachers, the physiological need could be in the form of the salary that the teachers receive. On the basis of this finding, money seems not to be a significant factor for teachers in this sample, as most teachers in this study would inherit wealth from their parents. This finding is not similar to the study done by Adjei and Amofa (2014), who found that wages and salaries were the most influential motivational factors among teachers in their study. This finding is also supported by Akintoye and Matthias (2000) who asserts that money remains the most significant motivational strategy. Money possesses substantial motivating power in as much as it symbolizes intangible goals like security, power, prestige, and a feeling of accomplishment and success.

In a study done by Morais, Neves, and Afonso (2005), it was found that teacher training led teachers to develop professionally. The teacher training program was even very positive for the teachers' competence. Teachers reached a higher awareness of the characteristics of their pedagogic practices. When asked about the importance of the training received, the teacher recognizes the importance of going beyond psychology and the needs to consider the sociological sides as well. By attending the teacher training, professional competence of all teachers is achieved.

The absence of the influence of teachers' job commitment to the teachers' competence may be caused by several factors. In this study, it is known that the factors that cause the absence of the influence of the teachers' job commitment to the teachers' competence could be due to scarcity of in-service workshops, trainings, and opportunity to attend seminars for the teachers to improve their ability, skills, and knowledge. This is certainly an important finding that teachers involved in this study still rarely have the opportunity to attend gatherings for their professional development. It is therefore important for the school and policymakers in the government to provide regular programs for teachers in the form of career and professional development activities. This suggestion is considered important since the teachers face new expectations and challenges so that they need to realize the existence of gaps between their current knowledge and what they need to know to become an expert teacher in the upcoming years in their professional career (Moeini, 2008). Especially for teachers taking part in this study where challenges do exist in the urban environments, they are really in need of broader context-specific trainings if they expect to serve in their long-term and challenging careers in teaching (Hanawar, 2008). Thus, to keep the teachers competitive and effective in today's knowledge-based world, as Majerič, Leskošek and Erpič (2011) recommended, the teachers are always being asked to remain trained and updated in their knowledge through training (Alam \& Farid, 2011). We can take the education system in Finland as an example (Hanhijoki, Katajisto, Kimari, \& Savioja, 2012). In Finland, the high level of training is deemed necessary as Finnish teachers are expected to be professionally autonomous. At most levels of education, teachers are required to participate in in-service training every year as part of their agreement on maintaining their salaries. In-service training is considered as a privilege for Finnish teachers to participate actively. In Finland, continuous attention is paid to both the teachers' pre-service and continuing education since they are recognized as the key to quality education.

Thus to meet the needs of teachers involved in this study, some teacher trainings could be prepared and organized by independent agencies. The British Council in Indonesia, for example, organizes annually some exciting events aimed at gathering teachers in the area where this study was conducted, conducting workshops on new methods, strategies/techniques in teaching various subjects, in addition to providing practical pedagogical techniques and up-to-date insights into EFL teaching which could help in the teachers' teaching 
practice. As Yulia (2013) has advocated, the training should be conducted to improve their knowledge for implementation in the classroom especially to raise students' motivation to learn English. She also added that teachers need to participate in such a training actively to improve their teaching professionalism. The training program as being a source of influence for the teachers' teaching has also been reported by Wati (2011), who found that the majority of the teachers indicated to have gained new skills and knowledge as a result of participating in the teacher training program. But despite the fact that such simple efforts help teachers to gain more information and improve the quality of their teaching, but the training programs have remain limited in number and frequency. Therefore, major efforts and initiatives have to be undertaken by schools and other educational institutions so that more and more teachers could be involved in different types of trainings and workshops for their professional development. At the national level, the Ministry could can help by forming national and/or regional councils of experts in the field of education to prepare training programs and collaborate with schools and universities to achieve these common goals, namely to refresh and improve the level of education of the teachers in this area.

As reported in the finding above, there is a significant influence of teachers' job satisfaction on the teachers' competence. This is in line with what has been found Pinder (2008) showing that a lack of job satisfaction is often accompanied by feelings of gloom, despair, anger, resentment, and futility that can influence the teachers' competence in the teaching and learning process. Thus, a lack of job satisfaction has severe implications for the teachers, as well as for the educational system in which they are employed. Also, it seems that one of the prime factors that affect the achievement of educational objectives of students is the scarcity of knowledgeability and satisfaction on the part of the teachers in the schools. One of the factors of job satisfaction that could influence teachers' competence is recognition. Andrews (2011) has advocated that recognition is one of the positive programs which can result in the better teachers' motivation. Recognition is also an award to the field of teaching and spotlight for students and the parents to have outstanding teachers in their schools.

To sum up, the regression coefficient of the independent variable teachers' motivation as indicated by the dimension of teachers' job satisfaction (X2) to the teachers' competence (Y) has been found to be significant. In the meantime, the independent variable motivation as indicated by job commitment (X1) to the teachers' competence (Y) showed some effect, although not at a significant level. Both motivation indicators (commitment and satisfaction) together have been found to have a significant impact on competence. Therefore, teachers' job satisfaction and their commitment to teaching are the crucial factors which could generally affect secondary school teachers, the school's employers, and students at large. For the success of any school in achieving its predetermined goals, committed and satisfied human resources are considered as the most critical assets. Thus, fostering commitment and satisfaction among teachers is essential because teachers, who are highly committed and satisfied, would tend to stay longer, perform better, and are actively involved in the work and engaged in organizational citizenship behavior.

\section{CONCLUSIONS}

It has been found that teachers' commitment to and satisfaction with their professional career, as indicators of their motivation, could have significant impact on their professional involvement, and that well-motivated teachers would tend to perform better, stay longer in the teaching profession, and get actively involved in social activities. Theoretically, this study has contributed to the current knowledge of motivation by identifying two main related research areas: teachers' motivation and teachers' competence, as well as how motivation and competence were interrelated to one another. Practically, this study will have some implications for enhancing the level of teachers' motivation. As teachers' motivation has been identified as a key determinant to teachers' competence, it is particularly useful for educational administrators to formulate practical strategies to stimulate teachers' motivation in order to improve their outcomes of teaching. In the same way, it could also become a stimulating factor for the teachers to self-stimulate themselves in order to improve their teaching capacity.

The results of this study have yielded quite a few implications for future research. It would be useful to conduct similar studies with participants not only teachers who teach EFL in senior high schools but also those who work with the students from elementary and junior high schools as well as at public and private colleges/universities, using a truly random sampling technique with different statistical tools such as path analysis, as teachers' job commitment and satisfaction are correlated with one another and together they affect teachers' competence. Another statistical tool that could be utilized is Partial Least Squares-Structural Equation Modeling, which does not require normality assumption and multicolinearity between independent variables. It is also suggested that future research should focus on whether teachers who are not motivated with their jobs could negatively affect students' academic performance and, vice versa, whether teachers who are wellmotivated with their jobs would have a positive impact on the students' performance. The findings suggest that teacher educators should focus efforts on helping teachers in improving their job commitment and job satisfaction. Therefore, discovering more about what makes a teacher feel committed and satisfied with his or her career choice is a worthy effort. Additionally, it may undoubtedly prove fruitful for school administrators and educational policymakers to learn how to structure and 
manage work environments to enhance teachers' levels of motivation via job satisfaction and job commitment.

\section{ACKNOWLEDGEMENT}

The first author would like to express her sincere thanks to Ministry of Research, Technology and Higher Education through a PKPI program in 2015, for its support to stay at Ohio State University where she was assisted by a counterpart in completing this research undertaking.

\section{REFERENCES}

Abdulsalam, D., \& Mawoli, M. (2012). Motivation and job performance of academic staff of state universities in Nigeria: The case of Ibrahim Badamasi Babangida University, Lapai, Niger State. International Journal of Business and Management, 2(5), 142-148.

Adjei, H., \& Amofa, A. K. (2014). Teacher motivation in senior high schools in the Cape Coast Metropolis. European Journal of Education and Development Psychology, 2(1), 18-25.

Akintoye, A., \& Matthias, B. (2000). Public-private partnership: managing risks and opportunities. Oxford: Blackwell Science.

Alam, M. T., \& Farid, S. (2011). Factors affecting teachers motivation. International Journal of Business and Social Science, 2(1), 298-304

Andrews, H. A. (2011). Supporting quality teaching with recognition. Australian Journal of Teacher Education, 36(12), 58-70.

Astuti, S. P. (2016). Exploring motivational strategies of successful teachers. TEFLIN Journal, 27(1), 1-22.

Atiya, I., \& Jehangir, P. (2012). Teachers' job performance: The role of motivation. Abasyn Journal of Social Science, 5(2), 78-79.

Aziz, F., Akhtar, M. S., \& Rauf, M. (2014). Relationship between teachers'competencies and motivation at higher education level in Pakistan. Pakistan Annual Research Journal, 50(1), 163174.

Bernaus, M., Wilson, A., \& Gardner, R. C. (2009). Teachers' motivation, classroom strategy use, students' motivation and second language achievement. Porta Linguarum, 12, 25-36.

Bishay, A. (1996). Teacher motivation and job satisfaction: a study employing the experience sampling method. Journal of Undergraduate Science, 3, 147-154.

Celep, C. (2000). Teachers' organizational commitment in educational organizations, Trakarya University, Edirne, Turkey. National Forum of Teacher Education Journal, 1(3), 1-21.

Darni, A. S. (2012). Hubungan antara motivasi mengajar dan kompetensi pedagogik dengan kinerja guru pendidkan agama Islam SD Negeri Kota Metro. Unpublished Thesis. Metro: Program Pascasarjana STAIN Jurai Siwo Metro.
Davidson, E. (2007). The pivotal role of teacher motivation in Tanzanian education. The Educational Forum, 71(2), 157-166.

Depdiknas. (2008). Permendiknas No. 16 Tahun 2007 tentang Standar Kualifikasi dan Kompetensi Guru. Depdiknas: Jakarta.

Depdiknas. (2005). Undang-Undang Nomor 14 Tahun 2005 tentang Guru dan Dosen. Jakarta: Depdiknas.

Dinham, S., \& Scott, C. (2000). Moving into the third, outer domain of teacher satisfaction. Journal of Educational Administration, 38, 379-396.

Dornyei, Z., \& Ushioda, E. (2011). Teaching and researching motivation. $2^{\text {nd }}$ edition. Great Britain: Pearson Education Limited.

Gayatri, A. W. (2006). Kontribusi motivasi kerja, kompetensi guru dan kepuasan guru terhadap kinerja guru mata pelajaran di SMA Negeri Kota Surakarta. Unpublished Thesis. Surakarta: Universitas Muhammadiyah Surakarta.

Gawel, J. E. (1997). Herzberg's theory of motivation and Maslow's hierarchy of needs. Practical Assessment, Research \& Evaluation, 5(11). Available online: http://PAREonline.net/getvn.asp?v=5\&n=11.

Guilloteaux, M. J., \& Dornyei, Z. (2008). Motivating language learners: A classroom-oriented investigation of the effects of motivational strategies on student motivation. TESOL Quarterly, 42(1), 55-77.

Hamalik, O. (2002). Perencanaan pengajaran berdasarkan pendidikan sistem. Jakarta: Bumi Aksara.

Hamied, F. A. (2017). Research methods: A guide for first time researchers. Bandung: UPI Press.

Hanawar, V. (2008, July 14). Urban districts found to be narrowing the teacher gap. Education Week. Retrieved December 16, 2016, from TNTP reimagine teaching: https://tntp.org/news-andpress/view/urban-districts-found-to-be-narrowingthe-teacher-gap.

Hanhijoki, I., Katajisto, K., Kimari, M., \& Savioja, H. (2012). Education, training and demand for labour in Finland by 2025. Finnish: National Board of Education and the authors.

Heery, E., \& Noon, M. (2001). A Dictionary of Human Resource Management. New York: Oxford University Press.

Herzberg, F., Maunsner, B., \& Synderman. (1959). The motivation to work (2nd. ed.). New York: John Wiley.

Iliya, A. \& Ifeoma, L.G. (2015). Assessment of teacher motivation approaches in the less developed countries. Journal of Education and Practice, 6(22), 10-17.

Jackson, C. M. (1997). Assisting marginal teachers: A Training Model. Principal, 77(1), 28-29.

Katane, I., \& Selvi. (2006). Teacher competence and further education as priorities for sustainable 
development of rural schools in Latvia. Journal of Teacher Education and Training, 6, 41-59.

Lockheed, M. E., \& Verspoor, A. M. (1991). Improving primary education in developing countries. Oxford: Oxford University Press.

Majerič, M., Leskošek, B., \& Erpič, S. C. (2011). The motivation of physical education teachers to participate in permanent professional training Courses: An analysis of selected factors. Kinesiologia Slovenica, 17 (1), 28-41.

Mangkunegara, A. A., \& Prabu, A. (2000). Manajemen sumber daya manusia. Bandung: Remaja Rosdakarya.

Maslow, A. H. (1987). Motivation and personality (3rd ed.). New York: Harper and Row.

Moeini, H. (2008). Identifying Needs: A missing part in teacher training programs. International Journal of Media, Technology and Lifelong Learning, 4(1), 112

Morais, A., Neves, I., \& Afonso, M. (2005). Teacher training and teacher's competence. A sociological study in the Primary School. Teaching and Teacher Education, 21, 415-437.

Ofoegbu, F. (2004). Teacher Motivation: A factor for classroom effectiveness and school improvement in Nigeria. College Student Journal, 38(1), 81-88.

Otube, N. W. (2004). Job motivation of teachers educating learners with special needs in four provinces in Kenya. Unpublished MA Thesis. University of Bonn.

Peck, R. F., Fox, R. B., \& Morston, P. T. (1977). Teacher effects on students' achievement and self esteem. Washington, DC: National Institute of Education.

Peretomode, V.F. (1991). Educational Administration Applied Concepts and Theoretical Perspective. Lagos: Joja Educational Research and Publishers.

Pinder, C. (2008). Work motivation in organizational behavior $2^{\text {nd }}$ edition. New York: Psychology Press.

Pintrich, P. R. (2003). A Motivational Science Perspective on the Role of Student Motivation in Learning and Teaching Contexts. Journal of Educational Psychology, 95(4), 667-686.

Reber, A. S., \& Reber, E. S. (2001). Dictionary of Psychology (2nd ed.). England: Penguin Books.

Sarmawa, I. W., Riana, I. G., \& Suryani, N. K. (2015). Commitment and competency as an organizational behavior predictor and its effect on the performance. International Journal of Economic, Commerce and Management, 3(1), 1-13.
Siagian, S. P. (2004). Teori motivasi dan aplikasinya. Jakarta: Rineka Cipta.

Singh, M., \& Singh, S. (2015). A study of teaching competence of school teachers in relation to their attitude towards ICT and teacher effectiveness. International Journal of Information Technology and Computer Sciences Perspectives, 4(3), 16301634.

Sriekaningsih, A. \& Setyadi. (2015). The effect of competence and motivation and cultural organization towards organizational commitment and performance on state university lecturers in East Kalimantan, Indonesia. European Journal of Business and Management, 7(17), 208-219.

Sriyono. (2005). Pengaruh motivasi kerja guru, pengalaman kerja guru dan profesionalisme guru terhadap kinerja guru SMK Muhammadiyah seKabupaten Klaten. Unpublished Thesis. Surakarta: Universitas Muhammadiyah Surakarta.

Suriyani, E., Hendriyani, S., \& Amsal, C. (2014). Pengaruh kompetensi dan komitmen terhadap kinerja guru SMA Negeri 1 Bunut Pelalawan. Jom Fekom, 2(1), 1-15.

Towse, P., Kent, D., Osaki, F., \& Kirua, N. (2002). Non-graduate teacher recruitment and retention. Teaching and Teacher Education, 18, 637-652.

Uno, H. B. (2008). Teori Motivasi. Jakarta: Erlangga.

Voluntary Service Overseas. (2002). What makes teacher tick? A policy research report on teachers' motivation in developing countries. Retrieved December 13, 2013, from vso: www.vso.org.uk/images/position papers_what_makes_teachers_tick_tcm8

Wati, H. (2011). The effectiveness of Indonesian English teachers training programs in improving confidence and motivation. International Journal of Instruction, 4(1), 79-104.

Yulia, Y. (2013). Teaching challenges in Indonesia: Motivating students and teachers' classroom language. Indonesian Journal of Applied Linguistics, 3(1), 1-16.

Yustiawan, F. H., \& Nurhikmahyanti, D. (2014). Pengaruh motivasi dan kompetensi profesional guru yang bersertifikasi terhadap kinerja guru di SMP Negeri 1 Surabaya. Jurnal Inspirasi Manajemen Pendidikan, 3(3), 114-123.

Zhang, Q., \& Sapp, D. A. (2008). A burning issue in Teaching: The impact of teacher burnout and nonverbal immediacy on student motivation and affective learning. Journal of Communication Studies 1(2), 152-68. 